\title{
Mannens stolthet
}

\author{
Normene for mannlig ansiktsbehåring har variert med historisk epoke, klassetilhørighet \\ og religion. Ikke alle vil si at skjegget er en pryd for mannen.
}

Hvorfor skal mannen ha skjegg? Skjeggvekst hører til de sekundære kjønnskarakterer som blir indusert av testosteron, og følgelig er det nærliggende å tro at det fremmer forplantningen. Med skjegg blir mannen attraktiv for kvinnen, og følgelig kan et fint skjegg være nokså avgjørende for at det kommer noen etterslekt. Men skjegg er mye mer enn som så, ettersom mannen selv kan bestemme hvordan og hvor langt skjegget skal være. Derfor er det like mye et uttrykk for mannens bilde av seg selv. I så måte atskiller det seg fra andre iøynefallende attributter hos mennesket, slik som nesen, $\varnothing$ rene og føttene. Der må vi finne oss i den fasongen og størrelsen de har fått.

Et skjegg har neppe noen betydning for sykdom og helse, med mindre bæreren lar være å vaske og gre det. Et skjegg som er fullt av smuler og andre forurensninger kan bli en kilde til vekst av skumle bakterier. Blir skjegget riktig stort, kan det få overraskende konsekvenser. Pianisten Kåre Siem (1914-86) gikk i mange år med et stort, grått, buskete skjegg. I et avisintervju ble han en gang spurt om det ikke var upraktisk. Det benektet han kategorisk. Likevel måtte han innrømme at det var litt problematisk at det stadig kom småfugler og ville bygge reir i skjegget.

Ser vi på skjeggvekst i en større sammenheng, er dette et enormt forskningsfelt for helsepersonell, sosiologer, antropologer og religionshistorikere. De ulike religionene gir detaljerte forskrifter for hvordan skjegget skal være, det samme finnes i ulike kulturer og samfunn. Ikke minst varierer type skjegg betydelig med historisk epoke. I den forbindelse har skjeggvekst vært satt i sammenheng med både visdom, virilitet, maskulinitet og høy status i samfunnet. Ikke minst har skjegget vært et varemerke for en rekke historiske personer (1). I dag kan vi ikke tenke oss at Christian Michelsen (1857-1925) kunne ha fungert som statsminister under den dramatiske epoken i 1905 uten sitt velpleiede fippskjegg. Og Henrik Ibsen (1828-1906) er utenkelig som nasjonalikon uten sitt brede, hvite fullskjegg.

Imidlertid har skjegget og bartens sosiale betydning vært altfor lite påaktet innen helsevesenet. Kanskje har vi oversett viktige personlige aspekter ved alle våre skjeggbærende menn, enten pryden arter seg som store, hvite ulldotter som gir utviskede konturer til ansiktet hos eldre mannfolk, eller det er stramme, mørke, fantasifullt klippede og prestisjegivende buskvekster hos yngre med appell og hos middelaldrende med autoritet.

Derfor var det velgjørende å lese Willy Mathisens lille artikkel om skjegg og skjeggfilosofi, som ble publisert i bladet Medisin og helse i 1983. Mathisen (1909-97) var overlege i kirurgi og ledet urologisk seksjon ved Rikshospitalet. Ved siden av å være en dyktig fagmann hadde han også evnen til å se oppover fra sin spesialitet i de nedre kroppsdeler og gjøre seg tanker om alt som vokste ut av mannens underansikt. Men nå er det lenge siden. Derfor er det på høy tid på ny å gjøre det norske helsevesen oppmerksom på hvilket komplisert fagfelt mannens pryd representerer.

\section{Ole Didrik Lærum}

ole.laerum@gades.uib.no

Ole Didrik Lærum (f. 1940) er professor (adj.) ved Københavns Universitet og professor emeritus ved Universitetet i Bergen.

\section{Litteratur}

1. Beard. Wikipedia. http://en.wikipedia.org/wiki/Beard (1.10.2012).

\section{Medisinske notater}

\section{SKJEGG - OG LITT SKJEGGFILOSOFI}

Av dr.med. Willy Mathisen. Medisin og helse 1983; nr. 1: 21-4.

Det skrives for lite om skjegg - til tross for at vi daglig formelig drukner i skjegg. Man må undre seg over hvorfor så mange unge menn ikler seg skjegg og langt hår i en tid da hygienen og friluftsliv dyrkes nesten uhemmet. Mange går sikkert med planer om å anlegge skjegg selv om de ikke egentlig vet hvorfor. Det gis ingen orientering eller informasjon av de ansvarlige myndigheter om skjeggets mange virkninger $-\mathrm{og}$ bivirkninger.

At moten spiller en stor rolle i denne forbindelse er sikkert. Moten har evnen til å bryte ned enhver hemning og personlig motstand, men spørsmålet er om det også kan ligge andre forklaringer til grunn for at menn forurenser sitt ansikt på denne måten.

La oss først se litt på hva skjegg er, og hvilken plass det har hatt gjennom historien. Skjegg er ingen ny invensjon. Det har en lang historisk bakgrunn. 

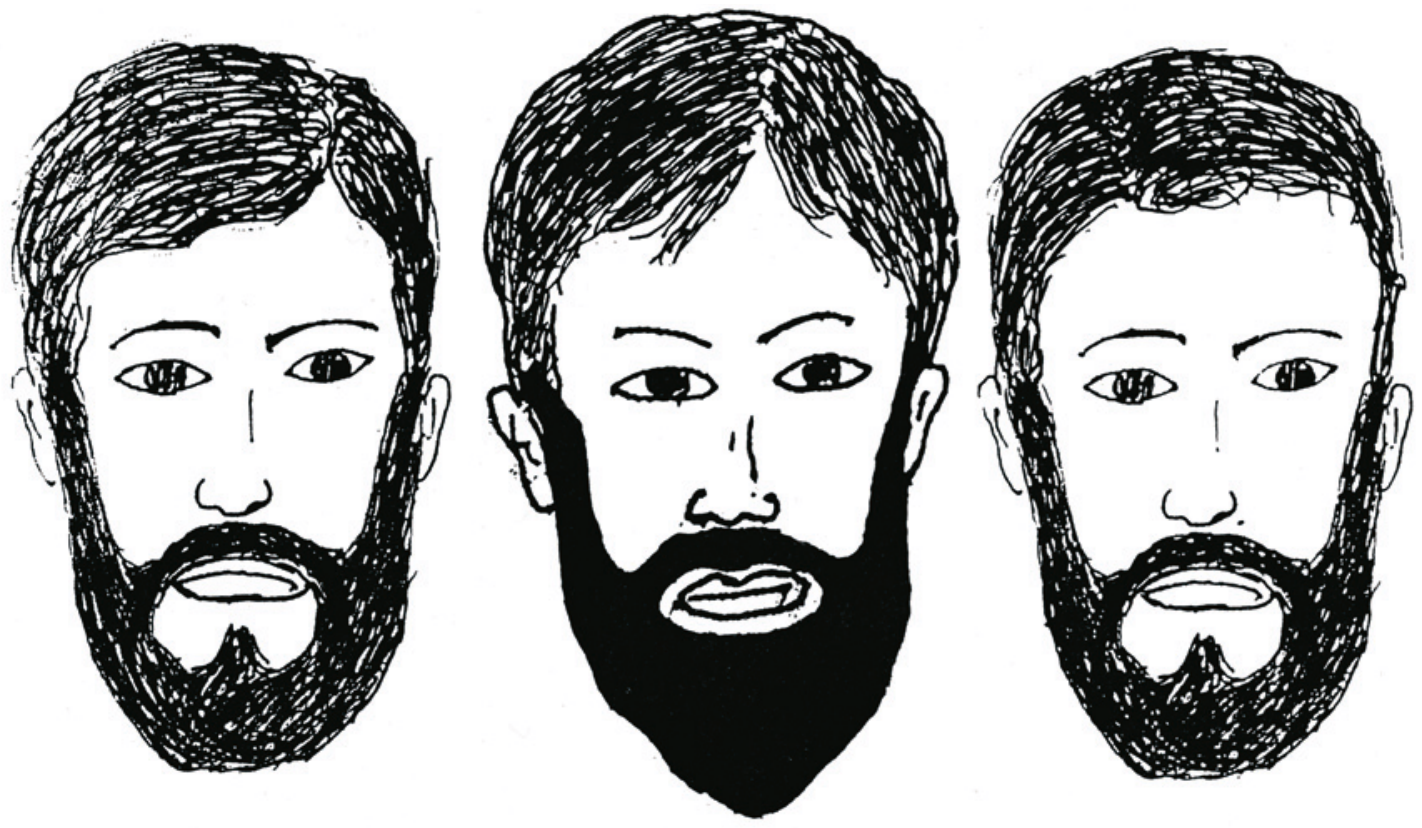

Fig 1. «Vis meg ditt ansikt» (selv om du ikke får se mitt). Fritt etter Karsten Isachsen.

Hva er skjegg?

I norrønt språk betegnet skjegg opprinnelig «ragget hårvekst» eller «geiteragg», og med dette mente man hårvekst på hake, kinn og overleppe hos menn. Det ble oppfattet som uttrykk for «full manndom». I de fleste europeiske språk er skjegg blitt betegnet med ord avledet av det latinske barbra (fransk: barbe, engelsk: beard, tysk Bart etc.). Hos oss er det tyske Bart blitt til skjegg på overleppen.

\section{Historikk.}

Skjeggmoten har gjennom historien skiftet med drakt og hårfrisyre, og skjegget har variert både i form og lengde.

I den eldre egyptiske historie brukte mennene ofte å krølle, farge og endog flette sitt skjegg. I den senere egyptiske epoke var mennene glattbarberte, men den høyere sosiale klasse kunne pynte seg med løsskjegg, ofte isprengt gulltråder som tegn på høy rang. Særlig var dette brukt i forbindelse med bestemte seremonier.

Hos hellenerne var skjegg og langt hår kjennemerke på filosofene. Etter perserkri- gene og i den tidlige keisertid skulle håret være velfrisert og ansiktet glattbarbert. Barberingen hadde vært på mote allerede flere hundre år før Kristus.

Etter hinduismens lære skulle både skjegg og hodehår gro og bli langt. Det samme krav ble stillet til de kristne under romertiden. Bare syndere barberte seg. Skjegget hørte til «Guds bilde», og å barbere seg ble betraktet som vanhelligelse av «Guds bilde». De ortodokse prester var pålagt å bære skjegg og ikke å klippe håret.

Helt siden Wilhelm Erobrerens tid (1066-87) har skjeggemoten vært «in» og «ut» med kortere eller lengre intervall helt til våre dager.

I begynnelsen av det 15 . århundre var skjegget forholdsvis kort og rett avskåret. Omkring 1550 ble hakeskjegget klippet til en spiss (fippskjegg) etter spansk mote. Samtidig skulle håret være skulderlangt og krøllet. I det 17. århundre kom parykkene, og skjegget og barten var ute av bildet. Omkring 1800 kom barten på mote. og håret som inntil da hadde vært kort ble gradvis lengre, og kort helskjegg og bart kom igjen.

Gjennom hele forrige århundre var bruken av skjegg vanlig, og skjeggformen kunne ha de underligste varianter fra frodige kinnskjegg til rene «julenisseskjegg». Motekravet var lite markert og det var opp til den enkelte å forme sitt skjegg etter personlig smak. Etter århundreskiftet forsvant skjegget for en tid, for så å dukke opp igjen som vi nå ser det rundt oss.

\section{Hvorfor skjegg idag?}

Da den siste skjeggepoke gjorde sin entré for ca. 10 år siden - var vel moten motivasjonen for de fleste. Mange nølte nok med å anlegge skjegg på den tid, og kom ikke med før skjeggmoten hadde hatt sin klimaks.

Etternølerne fant da ofte på forskjellige begrunnelser for skjegget. Det kunne være man mente ansiktet kunne strammes opp med litt skjegg. Endel eldre menn som hadde oppdaget begynnende rynker og
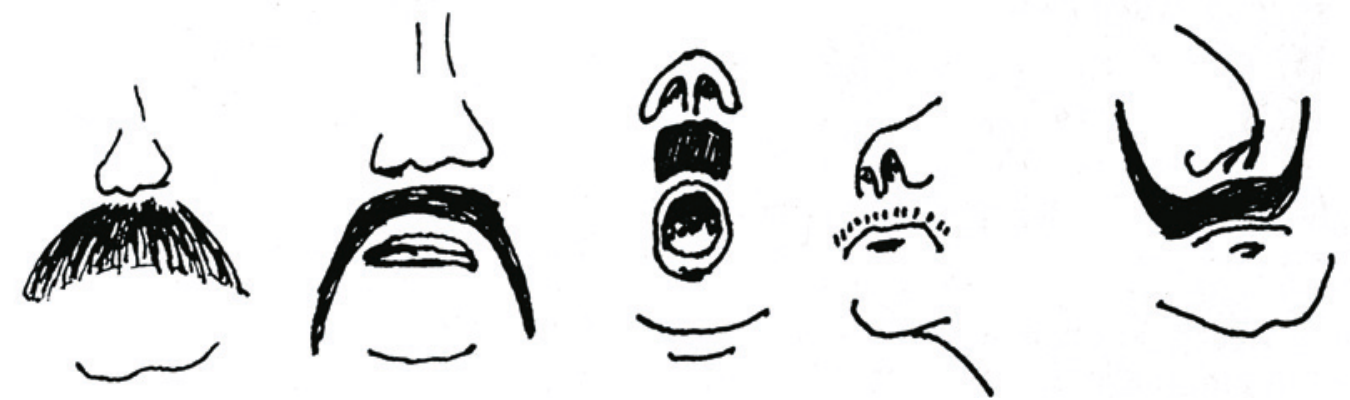
andre alderstegn i sitt ansikt lot skjegget vokse. På den måten kunne de så å si komme ut i ny utgave. Det var jo først og fremst de unge som nå hadde skjegg.

Skjegget som fysisk vern.

For menn med utearbeide kan nok skjegg i den kalde årstid gi en viss beskyttelse mot kulde. Tidligere var skjegg vanlig blant sjøfolk, men idag er sjøfolk ikke mer utsatt for vær og vind enn de som arbeider på land. Selv i kulde kan skjegget være til tvilsom nytte når istappene henger lange og tunge i skjegget.

\section{Skjegget som psykisk vern.}

Skjegget gir en følelse av å ha på en maske. Derved har man fătt et visst vern mot den harde verden omkring oss. Så lenge skjegg er på mote tilhører man en større gruppe de beskjeggete. Dette gir en viss følelse av trygghet og samhørighet - og valiumtablettene kan sløyfes.

At skjegget også kan fjerne visse hemninger kan av og til få mindre heldige utfall.

Skjegg og seksualitet.

Skjeggets virkning på det annet kjønn varierer meget. Enkelte kvinner kan ikke tenke seg å ha kontakt med en beskjegget, noe dyrisk utseende mann. På andre kvinner, kanskje mer romantiske, kan skjegg virke stimulerende idet de har en følelse av å stå overfor en særdeles maskulin type.

I de fleste tilfeller er imidlertid skjegg ikke nok, det skal mere til for å skape en personlighet.

\section{Skjegg og hygiene.}

Har man skjegg skulle man slippe å barbere seg daglig, og derved gjøre morgentoalettet enklere. Men skjegget krever også sitt stell. Omhyggelig renslighet er nødvendig for å unngå infeksjoner i hårroten. «Skjeggsopp» er meget plagsomt og fører til at skjegget må ofres. Skjegget må klippes og pusses - så helt enkelt er det allikevel ikke.

\section{Skjegg og hormoner.}

Skjeggets vekst og utseende er under påvirkning av de mannlige kjønnshormoner. Hos menn kommer skjegget først ved puberteten. De kvinnelige hormoner er antagonister (motvirkende) til de mannlige hormoner, derfor får ikke kvinner skjegg. Ved overgangsalderen stopper produksjonen av kvinnelige hormoner, og hos enkelte kvinner kan binyrenes produksjon av mannlige hormoner bli så sterk at det fører til utvikling av skjegg også hos kvinner - dog sjelden i større mengde.

Barten.

Barten, eller mustasjen, knebelsbarten etc. er en avart av skjegg. I virkeligheten er den en temmelig komisk variant. Ikke desto mindre har den fått ganske stor utbredelse. En engelskmann med respekt for seg selv må ha en bart. For andre er den vel ikke så nødvendig.

Barten har fått mange underlige utforminger, fra den noe triste nedadhengende type a.m. Kipling - til den mer oppadstrebende snurrbart, foruten de mange varianter av «tannbørstetypen» som vi kjenner fra enkelte komikere og komiske personer.
Resyme.

Skjegget har gjennom tidene vært det typiske mannlige attributt som mannen har yndet å ikle seg når han har villet markere sin maskulinitet. Sjelden kan skjegg bidra til å forskjønne et ansikt, men det kan skjule meget. Skjegget uniformerer - bærere av samme skjeggfasong er alle like. Det personlige særpreg er borte.

Moten mangler vanligvis all logisk bakgrunn. Den er oppstått etter det «fri innfalls metode». Hvis man imidlertid følger skjeggmotens svingninger gjennom tidene kan man spore en viss synkronisme med kvinneemansipasjonens skiftende intensitet. En forsterkning av kvinnebevegelsen har vanligvis vært etterfulgt av et oppsving av skjeggmoten, - som om mannen ville si: «se - vi er da menn». Om denne tolkning er helt korrekt vil jeg ikke innestå for. På dette felt trenges mer forskning. 